\title{
THE SIGNIFICANCE OF ISRAEL FOR THE CHURCH
}

Prof. J. A. van Rooy

The subject can be defined more specifically as follows:

What does God reveal to us about the Church of the New Testament through the election and calling of Israel?

\section{The relevant Old Testament}

It is evident from the very way in which this topic was formulated, that we are expected to start from the assumption that the Old Testament is relevant for the Church of the New Testament. This relevance is possible because it is the same God who reveals himself progressively through his mighty acts in history in both Testaments. According to the New Testament, the Church is the new people of God, and the most poignant words about the election, calling and destiny of the Church to be found in the whole of the New Testament are taken directly from the Old Testament: "You are the chosen race, the King's priests, God's own people, chosen to proclaim the wonderful acts of God ..." (1 Pt. $2: 8-9$, quoting from Ex. 19 : 5-6 and Hosea 1).

\section{The Kingdom of God in the Old Testament}

The theme of the Kingdom of God suggests itself as the obvious angle from which to view this subject.

The term "Kingdom of God" does not occur in the Old Testament in this exact form. The concept, however, is dominant from the very first words: "God created heaven and earth." 1 Being the sole and sovereign Creator, God rules over everything. He creates man as his subject, for the purpose of ruling over this creature of his in personal fellowship with him. This fellowship manifests itself in the different forms of covenant concluded by God with man in the course of the history of salvation.

But hand in hand with this theme, throughout the history of salvation, runs the parallel theme of the utter failure of man, even of the chosen people. Man falls unto death, yet in the course of history through the ages God upholds his sovereign rule over man by again and again creating, so to say, life from death. Man in his turn time and again gradually turns his back on God and ends in death.

This rebellion starts at the fall of man from his state of innocence, is manifested again at the Tower of Babel, in the spiritual death of Israel in it's slavery in Egypt, in it's absorption, many times over, into the naturalistic religion of Canaan, and in the events leading finally to the Babylonian exile, to mention only a few conspicuous examples.

Despite the failure of man, God upholds his sovereign rule by creating life from death after every fall or decline. After the murder of Seth, he gives and maintains the line of the faithful from Abel to Noah. After the rebellion at Babel he eventually calls Abram to be the father of his peculiar people. He delivers his people from slavery and apostasy in Egypt. After each apostasy in Canaan $\mathrm{He}$ 
sends charismatic leaders to deliver his people and to call them back to their Lord, through the time of the judges, and the glorious revival in the time of Samuel and David, when even the practice of sacrificing in the "high places" seems to have carried no danger of Baalistic syncretism, and through to the return of a remnant from the exile. Every time it is God who creates life from death.

\section{Failure and renewal in the New Testament Church}

This theme finds its highest fulfilment in the vicarious death and resurrection of God's own Son, who ascends to heaven and pours down his Spirit on his Church with the promise that He will stay with them for ever. Yet even this glorious new dispensation is not without its disappointments. However incongruous it might seem with the new dispensation, the theme of apostasy repeats itself with monotonous regularity. Times of spiritual high-tide are followed by periods, sometimes lasting for hundreds of years, of spiritual lowtide, when God becomes remote and unreal and irrelevant to the Church, and she sometimes closely resembles the valley of dry bones in the vision of Ezekiel 37.

I believe that the well-known phenomenon of revival and reformation which we encounter in the history of the Church, to the extent that it is initiated by the Holy Spirit and not by men, is a manifestation of the same sovereign God upholding his rule in the same way as in the history of the Old Testament. This is what we find in the Reformation of the Sixteenth Century, in the Great Awakenings of the Eighteenth and Nineteenth Centuries, in East Africa and Korea, in modern Russia and in many other instances of lesser scope.

It should be borne in mind that, the Holy Spirit being the sovereign Lord establishing his sovereign rule in our lives, He can never be manupilated. We cannot direct $\mathrm{Him}$ as to how or when $\mathrm{He}$ has to create life from death. We can only pray and submit ourselves to his sovereign rule and follow as He leads us and wait his good time.

\section{There are still "valleys of dry bones"}

In what forms does this decline and death manifests itself in the New Testament people of God? In more than one form. When natural man gets the upper hand in the Church, he inevitably flees from the personal fellowship with God which the covenant implies and settles in a dead orthodoxy and lifeless legalism and ritualism, where rites are supposed to work ex opere operato, outside the context of covenant love. This is what Isaiah refers to when he delivers God's message: "Who asked you to bring all this when you come to worship Me? Who asked you to do all this tramping about in my Temple? It's useless to bring your offerings. I am disgusted with the smell of the incense you burn ... Stop all this evil that I see you doing ... See that justice is done - help those who are oppressed, give orphans their rights, and defend widows." (Is. $1: 12-13,16-17$ ).

In the New Testament Church this ritualism manifests itself where the orthodox liturgy is still used, but for the greater part of the visible Church it has lost it's meaning and none of the truths 
for which it stands are any more accepted: the most sublime doxology is shanted by a theologian who has long since lost his faith in the God of the Bible. Preaching of the Word can only be described as a travesty. Holy Communion is celebrated by scores of people who have no part or faith in the redeeming and substitutionary sacrifice of Christ, nor any understanding of it, and it never troubles anyone, it never even strikes anyone as insincere.

It is also manifested where orthodox Biblical doctrine is still adhered to, where there is still "the outward form of religion", but the essence of the covenant: the fellowship with the living God and the compassion for one's fellow man which flows from that has long since vanished.

\section{Misunderstanding election}

If Israel does not "know" God any longer in the Biblical sense, if she is no longer "the King's priests", she can no longer proclaim his wonderful acts. She ceases to have any positive function in his Kingdom.

Ironically, it is at the point of her deepest failure that Israel cherishes the highest notions about herself, following the deception that she was chosen on account of her own excellence, feeling secure in the illusion that she can therefore never be rejected. "All the promises of God in history are equated with the existing order and made realizable in terms of it." "However, Israel was not elected because of any merit whatsoever on her side, but solely, exclusively, on account of God's free grace; neither was she elected for her own benefit, but as a witness to the Kingdom of God.

\section{False prophecy; nationalist theology}

The inevitable result of Israel's misinterpretation of her election and calling is a kind of nationalist theology which makes religion, and even God Himself, subservient to the interests of the "establishment" - and how familiar this sounds! Now let us be quite clear on this point: When the foregiving is applied to our own situation it is by no means implied that all theology practised by people sympathetic to the establishment is nationalist theology. This would be very far from the truth. All theology practiced by Whites is not necessarily "white theology", just as all theology practised by Blacks is not necessarily "black theology". What I say here is true of "White theology". That is the kind of theology that is practiced when the people of God, the Church, forgets its high calling and henceforth exists solely for itself and teaches its members that its highest calling is to safeguard its own interests and future.

This is where the false prophets come in. There are always people who can size up the mood of a people and who are willing to jump on the bandwagon and ride to the crest of popularity. In the case of Israel's (and our!) religion this explains the baneful phenomenon of false prophecy. False prophets are mentioned as early as the time of Ahab in Israel when we find them confronting Micah ben Imlah the prophet of Jahweh, assuring Ahab of victory over the Syrians. Doubtless they were not a new phenomenon then, and 
they persisted right through to the time of Jeremiah and the exile, when at last their falseness was demonstrated in all its harmful effects. Micah had many less flattering things to say about harmful prophets: "My people are deceived by prophets who promise peace to those who pay them, but threaten war for those who don't. To these prophets the LORD says: Prophets, your day is almost over; the sun is going down on you." $(3: 5-6)$.

It seems as if this scourge is part of God's punishment on a people that has turned its back on Him. He gives them the kind of prophet they want, to tell them what they like to hear, so as to hasten their fall. They won't listen to God's own message, so: "Make the minds of these people dull", the LORD tells Isaiah, "their ears deaf and their eyes blind, so that they cannot see or hear or understand." (Is. 6:10). They won't listen to God's own message, so he leaves them to the false prophets of their own choice.

The deeper Judah fell into apostasy, the more stubborn she became in her suicidal conceit, encouraged by the false prophets. By the time of Jeremiah it was clear that they were determined to persist to the bitter end.

When catastrophe struck Judah and the judgment which had been foretold by the true prophets was executed, the false prophets and those who followed them had no hope of retaining their religion. They had staked everything on a deception, and only embarrassment remained. The past had to be forgotten as soon as possible. We should take note of this.

The true prophets of Yahweh, however, with those who had listened to their teaching, were vindicated, and for them the doom was a strengthening of their faith in the God who is in sovereign control of history, because everything happened as was forctold by his prophets.

History is not the norm of God's will for the future.

God is the Lord of history who reveals himself through his acts in history, but we should not deceive ourselves by concluding that history is therefore normative. This is a rather popular theme among ruling classes in South Africa. As long as it suits them to regard it this way, ie. as long as history goes their way and seems to favour them, they are very quick to identify history with the revelation of God's will for the future. They are favoured by the course of history - so far at least - and from that they conclude that God intends them to be the favoured ones ad infinitum.

This was the kind of theology that Amos fulminated against. You see: I do not believe that the social message of Amos is the only message that the Old Testament has for us, but neither do I believe that we can ignore it. Apostasy from God, breaking his covenant, of necessity leads to the social desintegration of a community.

\section{Judgement}

So history is not normative in itself after all. History needs to be interpreted by prophecy - not by the false prophecy that panders to popularity, but by inspired prophecy that asks what the will of 
God is. And the will of God towards an apostate people is "naught for its comfort". If God is real and holy, there is no alternative to judgement. It is simply not true that God is only love. He is also just in his judgement on sinners. What He says of Niniveh in Nahum (1:3a): "The Lord does not easily become angry, but he is powerful and never lets the guilty go unpunished", is also valid, even in a higher degree, for his own people. Amos says, "Of all the nations on earth, you are the only one I have known and cared for. That is what makes your sins so terrible, and that is why I must punish you for them." (Amos 3:2).

It seems as if the message of Amos hardly leaves scope for mercy. "These people fill their mansions with things taken by crime and violence. They don't even know how to be honest. And so an enemy will surround their land, destroy their defences, and plunder their mansions ... You are doomed, you that twist justice and cheat people out of their rights! . . . You people hate anyone that challenges injustice and sneaks the whole truth in court. You have oppressed the poor and robbed them of their grain, and so you will not live in the fine stone houses you build or drink wine from the beautiful vineyards you plant. I know how terrible your sins are and how many crimes you have committed. You persecute good men, take bribes and prevent the poor from getting justice in the courts .. Listen to this, you women of Samaria, who grow fat like the wellfed cows of Bashan, who ill-treat the weak, oppress the poor, and demand that your husbands supply you with liquor! As the Sovereign Lord is holy, He has promised: 'The days will come when they will drag you away with hooks; every one of you will be like a fish on a hook. You will be dragged to the nearest break in the wall and thrown out."' (Amos $3: 10-11 ; 5: 7,10-12 ; 4: 1-3$ ).

The punishment for those who have broken the covenant is worse than for those who have never been in this relationship to God. The judgement starts at the house of God. (1 Pt. 4:17). This is inherent in the very nature of the covenant. One thinks of the symbols of slaughtered animals through among which the parties in the covenant of God with Abraham had to pass, which hinted at this judgement, or of the severe threats in Lev. 26:14-15 and Deut. $28: 15-68$. If a vassal rebels against the Great King, the punishment is terrible!

So let us beware. Election does not imply that the Church is in any way more worthy of it than anybody else, and the moment she starts imagining that she was elected because of any merit in herself, or for the own benefit and exaltation she thereby merely proves that she is probably reprobate rather than God's chosen people.

\section{Persecution for God's sake}

Strangcly modern is also the way in which faithful prophets are persecuted and victimized. There are many examples of this, but the most striking is Jeremiah, the most sincere patriot of his time, who was more than once accused of treason, imprisoned, and but for the protection of Ahikam, would certainly have been executed for telling his people God's message. 
When I look over the audience in this lecture hall, I can see the faces of those brethern who have been persecuted and slandered by their own fellow ministers and Church members, have had invitations to preach and lectures cancelled and been barred from positions of trust and influence which they deserved, for no other reason that that they were faithful in declaring the implications of the covenant and the rule of God in their preaching and Church councils.

\section{Prophecy and hope}

Israel had to fall under God's judgement, yet since election is the decree of a sovereign God, man's failure is not God's failure. He remembers his promises even when his people has rejected him, and in his own good time he maintains his sovereign rule by again creating life from death. He sends the message of a glorious hope beyond judgement, when he will cause a remnant to repent and be saved to carry forward his purposes. Being the sovereign Lord, his Kingdom will finally be vindicated and demonstrated to be invincible. In the deepest darkness shines the brightest light. In the almost inconceivable destruction of the Assyrian conquest of Judah, Isaiah receives the promise of the eternal Ruler to come, (Is. 8 and 9) at whose coming a banquet will be prepared for all the nations on mount Zion, and death, the cloud of sorrow that has been hanging over all the nations, will suddenly be lifted. Isaiah can even sing songs of joy and praise under these circumstances, because not even the destruction he sees can take away his glorious hope. (Isaiah 12). This is as relevant for us as for him. If we are really God's people, the Church of Christ the Lord, though we lose everything in this world, we have not really lost anything. And since we have this glorious hope we should not live as people do who have nothing except this world to live for.

\section{The remnant}

But there is also hope for the people of God in this world, and this hope is concentrated in the prophecy of a repentant and faithful remnant that will emerge from the judgement.

We should never forget that this was aimed at a remnant. No people on this earth can claim to be God's people any more. God's true people will always be in the people. There is no promise of a perfect theocratic society in this world before the coming of Christ. Scripture focuses our hope beyond this world, or at least beyond this dispensation (if we are millennialists), and we should always keep this in mind. This society can never be perfect. Usually only a minority in it really recognizes the rule of God, and even they very imperfectly. We remain sinners.

But this does not mean that God is not ruling now. On the contrary, his Kingdom has come, and he demands uncompromising obedience from his subjects. A Church which claims to be God's people has to acknowledge him as Saviour, but we cannot acknowledge him as Saviour and refuse him as Lord. There is no such thing as a half Messiah. 


\section{The Suffering Servant}

The final theme from the Old Testament that remains to be applied to the Church of the New Testament is one that seems to become more and more relevant in our own time. That is the theme of the Suffering Servant, found in the second part of Isaiah.

Fluid as this figure might be, referring first to the thing and then to another, it cannot be denied that it also refers to the remnant Church, that is still called to be a blessing to the world, to "to be the vessels of his redemption, to bring Israel back to itself and to proclaim his salvation in the entire world. To be sure, Israel will find in this destiny no exemption from suffering, but precisely a summons to it. Yet suffering will be transfigured: no longer will it be ... brute agony without meaning, but the very instrument of redemption. In it Israel will enter into the very character of God's Servant and share in his redemptive purpose. Through its agony its original destiny in Abraham to be a blessing to all mankind is put before it again."

In a setting where there are prophets who urge a Church, or a people, for that matter, that in order to be a blessing to other peoples its first concern should be the safeguarding of what is called its "identity", if necessary with brute force and repression, is not this what God wants us to listen to? Can we serve a Messiah who appears as a Suffering Servant and who demands of us to reflect his image, if we preach a gospel of love and justice and righteousness while at the same time answering the aspirations of subject peoples with nothing but more and more repressive measures the stronger their clamour becomes for what they regard as their rights and the stronger their resistance to suppression becomes? One must be blind to refuse to realize that this only creates a vicious circle which will one day be broken by force, and the longer the delay, the greater the force.

Must we really be the rulers in order to keep our "identity" intact? Must we really be the rulers in order to be the bearers of God's message? Will our message not be more credible if we demonstrate more of the character of our Suffering Saviour? Shall we not lose our identity, our lives, for the very reason that we have made a first priority of it?

Israel had actually, literally, to lose her identity as a political entity. She had to lose her country and be scattered all over the world. She had to lose her language for two thousand years or more, and by the time the Messiah came, Jews were speaking the world languages, Aramaic and Greek, and using Targums and Greek translations of their holy scriptures, which in that way became a religious community in a cosmopolitan world empire. And there she was more the people of God than ever before.

If a Church wants to save its own life, according to the Law of Christ's Kingdom, it will lose it, but if it is prepared to lose its life for the sake of God's Kingdom, it wil save it. (Mk $8: 35$ ). 
20 In die Skriflig

Will our "identity" not be granted to us as a gift, because we have sought first the Kingdom of God and to do his will?

Paper read at joint congress of theological societies January 1983 at Pretoria.

\section{NOTES}

1. Helberg, J. L. Die Here regeer. Pretorla: N. G. Kerkboekhandel, 1980; Floor, L. Die evangelie vin die koninkryk. Pretoria: N. G. Kerkboekhandel, 1981.

2. Bright, John. The Kingdom of God. Nashville: Abingdon, 1950, p.43 (see also p. 64-65).

3. Ibid, p.153. 